\title{
ANALISIS DAMPAK KEBERADAAN PASAR MODERN TERHADAP PASAR TRADISIONAL SLEKO DI KOTA MADIUN
}

\author{
Mahmudah Masyhuri ${ }^{1}$ \\ Pendidikan Akuntansi \\ Universitas PGRI Madiun \\ mahmudahmasyhuri@gmail.com
}

\author{
Supri Wahyudi Utomo ${ }^{2}$ \\ Pendidikan Akuntansi \\ Universitas PGRI Madiun
}

\begin{abstract}
ABSTRAK
Penelitian ini bertujuan untuk: 1) Mengetahui dampak keberadaan pasar modern Alfamart dan Indomaret terhadap pasar tradisional Sleko di Kota Madiun, 2) Mengetahui apakah keberadaan pasar modern Alfamart dan Indomaret menyebabkan turunnya aktivitas pasar tradisional Sleko di Kota Madiun. Teknik pengambilan sampel dipilih dengan teknik probability sampling yaitu sebanyak empat pedagang tradisional dari masing-masing kategori pedagang yang diteliti dan satu orang dari pengelola pasar tradisional yang diwakili oleh Kepala Pasar Sleko Kota Madiun, serta empat pembeli di pasar tradisional Sleko dan empat pembeli di pasar modern Alfamart dan Indomaret. Hasil menujukkan bahwa dampak keberadaan pasar modern Alfamart dan Indomaret terhadap pasar tradisional Sleko di Kota Madiun yaitu pedagang sayuran dan pedagang buah tidak mengalami pengaruh terhadap omset dan konsumen. Sedangkan dampak bagi pedagang sembako yakni mengalami turunnya omset dan berkurangnya konsumen. Oleh karena itu, keberadaan Alfamart dan Indomaret tidak menyebabkan menurunnya aktivitas pasar tradisional Sleko dalam hal jual beli. Pasar Sleko pun masih memiliki konsumen walaupun keberadaan Alfamart dan Indomaret berlokasi di dekat pasar.
\end{abstract}

Kata Kunci : Omset; Jumlah Konsumen; Aktivitas Pasar; Pasar Modern; Pasar Tradisional

\begin{abstract}
This research aims to: 1) Know the impact of existence of modern market of Alfamart and Indomaret to Sleko traditional market in Madiun City, 2) to know whether existence of modern market of Alfamart and Indomaret cause decreasing activity of Sleko traditional market in Madiun City. The sampling technique was chosen by probability sampling technique as many as four traditional traders from each category of traders studied and a person from the traditional market manager represented by Head of Sleko Market, and four buyers in Sleko traditional market and four buyers in modern market Alfamart and Indomaret. The results show that the impact of the existence of modern market Alfamart and Indomaret against Sleko traditional market in the city of Madiun namely vegetable traders and fruit traders do not affect the turnover and consumers. While the impact for food traders that experienced a decrease in turnover and reduced consumer. Therefore, the existence of Alfamart and Indomaret does not lead to declining activity of traditional Sleko market in terms of buying and selling. The Sleko market still has consumers despite Alfamart's presence and Indomaret located near the market.
\end{abstract}

Keywords: Turnover; Number of Consumers; Market Activity; Modern market; Traditional market

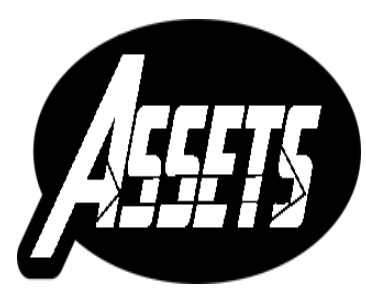

ASSETS:

Jurnal Akuntansi dan Pendidikan Vol. 6 No. 1 Hlmn. 59-72

Madiun, April 2017 p-ISSN: 2302-6251 e-ISSN: 2477-4995

Artikel masuk: 8 Februari 2017 Tanggal diterima: 21 Maret 2017 


\section{PENDAHULUAN}

Masyarakat perkotaan kini sangat dimanjakan oleh berbagai pusat perbelanjaan. Terkadang letak perbelanjaannya saling berdekatan satu dengan yang lainnya, baik yang tradisional maupun yang modern. Kondisi ini sangat menguntungkan masyarakat karena mereka tinggal memilih gerai mana yang akan dituju. Disatu sisi dengan maraknya bisnis ritel yang memasuki daerah-daerah akan membuat konsumen dimanjakan karena memiliki banyak pilihan dalam berbelanja. Namun disisi lain, pasar tradisional yang memasok kebutuhan konsumen lambat laun tergencet.

Maraknya bisnis retail (ritel) juga dialami di Indonesia. Bisnis ini sudah bukan hanya berdiri di kabupaten dan perkotaan saja, melainkan sekarang sudah berdiri di berbagai kecamatan maupun pedesaan. Contoh bisnis ritel yang terkenal di kalangan masyarakat saat ini yaitu Alfamart dan Indomaret. Maraknya bisnis eceran yang terjadi saat ini sangat menumbuhkan minat berbelanja di kalangan masyarakat, karena baik Alfamart dan Indomaret menyediakan berbagai macam produk sehari-hari dengan harga yang sudah tertera jelas dalam produk, ketersediaan layanan 24 jam, tempat lebih nyaman, lebih bersih, sistem pemilihan dan pengambilan barang sendiri oleh konsumen sehingga memudahkan masyarakat untuk membeli serta mendapatkan barang yang dibutuhkan dengan segera. Selain itu dengan pelayanan yang ramah dan sering melakukan diskon serta promo produk, Alfamart dan Indomaret sangat diapresiasi keberadaannya oleh masyarakat sekitar karena sangat memuaskan. Bahkan dengan berbelanja di Alfamart maupun Indomaret dan memiliki kartu keanggotaan, konsumen akan mendapatkan poin atau mendapat potongan harga.

Banyaknya pasar modern Alfamart dan Indomaret yang tumbuh di masyarakat memiliki suatu keuntungan serta kerugian. Keuntungan yang didapatkan yaitu sangat memenuhi kebutuhan konsumen serta menjadi suatu lapangan pekerjaan bagi masyarakat sekitar. Kerugiannya yaitu maraknya pasar modern akan berdampak terhadap keberadaan pasar tradisional. Karena mayoritas produk yang dijual di pasar modern Alfamart dan Indomaret itu sama dengan produk yang dijual di pasar tradisional. Banyak orang yang berpendapat bahwa salah satu faktor menurunnya kegiatan di pasar tradisional karena banyaknya pasar modern Alfamart dan Indomaret yang tumbuh dan lokasinya sangat berdekatan dengan pasar tradisional sehingga berdampak pada usaha para pedagang kecil di pasar tradisional. Munculnya pasar modern menyebabkan penurunan jumlah konsumen pada pasar tradisional karena adanya pasar modern diikuti dengan adanya perubahan preferensi masyarakat dalam memilih tempat belanja.

Pasar memiliki pengertian tempat bertemunya penjual dan pembeli sampai terjadinya suatu transaksi. Saat ini, pasar yang terjadi di dalam lingkungan masyarakat sudah tidak hanya pasar tradisional. Nuraini dan Merdekawati (2013: 65) berpendapat bahwa pasar tradisional menekankan arti pasar secara fisik, sehingga pasar tradisional juga sering disebut sebagi pasar konkret. Asribestari dan Setyono (2013: 541) menjelaskan bahwa pasar tradisional ialah pasar dimana penjual dan pembelinya melakukan tawar menawar secara langsung sehingga terjadi kesepakatan harga antara kedua belah pihak. Rahayu dan Bahri (2014: 158) berpendapat bahwa pasar tradisional adalah pasar yang dikelola dengan manajemen yang lebih tradisional dan lebih simpel dari pada pasar modern. Pasar tradisional bersifat kepemilikan perseorangan. Eksistensi pasar tradisional merupakan salah satu indikator paling penting dalam kegiatan perekonomian (Sukesi dan Sugiyanto, 2009: 156).

Menurut Wiboonpongse dan Sriboonchitta (dalam Aryani, 2011: 175) pedagang tradisional mempunyai karakteristik yang kurang baik dalam strategi perencanaan, 
terbatasnya akses pemodalan yang disebabkan jaminan (collateral) yang tidak mencukupi, tidak adanya skala ekonomi, tidak mempunyai jaminan kerja sama dengan pemasok besar, manajemen pengadaan yang buruk, dan lemahnya kemampuan dalam menyesuaikan keinginan konsumen. Selaras dengan itu Utomo (2011: 127) mengemukakan pendapatnya mengenai karakteristik pasar tradisional. Adapun karakteristik yang dikemukakan olehnya yaitu:

Tabel 1. Karakteristik Pasar Tradisional

\begin{tabular}{|c|c|c|}
\hline No & Aspek & Pasar Tradisional \\
\hline 1 & Histori & Evolusi panjang \\
\hline 2 & Fisik & Kurang baik, sebagian baik \\
\hline 3 & Pemilikan/Kelembagaan & Milik masyarakat/desa, pemda, sedikit swasta \\
\hline 4 & Modal & $\begin{array}{l}\text { Modal lemah/subsidi/swadaya masyarakat/ } \\
\text { inpres }\end{array}$ \\
\hline 5 & Konsumen & Golongan menengah kebawah \\
\hline 6 & Metode pembayaran & Ciri dilayani, tawar menawar \\
\hline 7 & Status tanah & Tanah negara, sedikit sekali swasta \\
\hline 8 & Pembiayaan & Kadang-kadang ada subsidi \\
\hline 9 & Pembangunan & $\begin{array}{l}\text { Umumnya pembangunan dilakukan oleh } \\
\text { pemda/desa/masyarakat }\end{array}$ \\
\hline 10 & Pedagang yang masuk & $\begin{array}{l}\text { Beragam, massal, dari sektor informal sampai } \\
\text { pedagang menengah dan besar }\end{array}$ \\
\hline 11 & Peluang masuk/partisipasi & $\begin{array}{l}\text { Bersifat massal (pedagang kecil, menengah, dan } \\
\text { bahkan besar) }\end{array}$ \\
\hline 12 & Jaringan & Pasar regional, pasar kota, pasar kawasan \\
\hline
\end{tabular}

Sumber: Utomo (2011)

Jika dilihat dari aspek-aspek karakteristik pasar tradisional, maka persaingan antara pasar tradisional dengan Alfamart dan Indomaret bisa terjadi. Pola belanja masyarakat modern yang menginginkan kenyamanan, kebersihan, promosi serta efisien dalam belanja menyebabkan pasar tradisional semakin ditinggalkan konsumen. Terlebih jika tidak ada usaha-usaha dari kepala pasar selaku pengelola pasar tradisional untuk melakukan perbaikan ke dalam maupun lingkungan di sekitarnya.

Menurut Peraturan Daerah Kota Madiun Nomor 32 Tahun 2011 (2011: 5-6) tentang retribusi pelayanan pasar menyebutkan komponen-komponen pasar tradisional dibagi menjadi beberapa jenis, yaitu: (1) Kios adalah bangunan permanen di dalam pasar yang digunakan untuk tempat usaha berjualan yang masing-masing dibatasi dengan tembok penyekat dan penutup pintu kios, (2) "Bedag" adalah los pasar berlantai keras, beratap yang dipetak-petak dengan penyekat permanen dan atau semi permanen yang dapat dipergunakan untuk tempat usaha berjualan, (3) Los adalah unit bangunan di dalam pasar, beratap dan berlantai keras yang dapat dipergunakan untuk tempat usaha berjualan dengan luasan yang telah ditetapkan, (4) Luar los adalah landasan di dalam pasar dan luar pasar baik yang berlantai keras maupun area terbuka yang dapat dimanfaatkan untuk tempat berjualan dan atau tempat promosi produk pabrikan.

Berbeda dengan pasar tradisional, karakteristik pasar modern ada pada Tabel 2.Dari segi karakteristik pasar modern memiliki keunggulan dibandingkan pasar tradisional. Pasar retail dan pasar tradisional tidak menutup kemungkinan akan terjadi persaingan, persaingan terjadi ketika masyarakat memilih satu diantara keduanya. Umumnya hal itu dipengaruhi oleh perilaku konsumen. 
Tabel 2. Karakteristik Pasar Modern

\begin{tabular}{|c|c|c|}
\hline No & Aspek & Pasar Modern \\
\hline 1 & Kualitas produk & $\begin{array}{l}\text { Berkualitas khususnya untuk bahan yang tahan } \\
\text { lama }\end{array}$ \\
\hline 2 & Kualitas pelayanan & Melayani sendiri, terdapat pencatatan transaksi \\
\hline 3 & Harga & Murah, terdapat bandrol yang jelas \\
\hline 4 & Variasi produk & Sangat bervariasi \\
\hline 5 & Merk produk & Beragam dan menjadi pertimbangan konsumen \\
\hline 6 & Lokasi & Mudah dijangkau, dekat perumahan \\
\hline 7 & Promosi & $\begin{array}{l}\text { Tinggi, beragam media, program diskon, bonus } \\
\text { hadiah langsung }\end{array}$ \\
\hline 8 & Penanganan keluhan & $\begin{array}{l}\text { Tidak langsung, penaganannya terstandarkan } \\
\text { dan terdokumentasi }\end{array}$ \\
\hline 9 & Cara pembayaran & Cash, debit card \\
\hline 10 & Keluasan gerak konsumen & $\begin{array}{l}\text { Tinggi, sempit untuk pasar retail (modern) yang } \\
\text { relatif kecil }\end{array}$ \\
\hline 11 & Keamanan & Aman \\
\hline 12 & Parkir & Luas, teratur \\
\hline 13 & Fasilitas tambahan & Troli, kartu pembayaran via bank, WC, mushola \\
\hline 14 & Kebersihan & Sangat bersih \\
\hline 15 & $\begin{array}{l}\text { Kemudahan menemukan } \\
\text { lokasi untuk jenis produk } \\
\text { yang diinginkan }\end{array}$ & Mudah \\
\hline 16 & $\begin{array}{l}\text { Kedekatan personal dengan } \\
\text { pedagang }\end{array}$ & Rendah \\
\hline 17 & Kesegaran & Cukup \\
\hline 18 & Sayuran organik & Rendah \\
\hline 19 & Kemudahan & Troli \\
\hline
\end{tabular}

Sumber: Aryani (2011: 176-177)

Sarwono dan Sunyoto (2014:68) mengemukakan bahwa perilaku konsumen adalah deskripsi tentang bagaimana konsumen mengalokasikan pendapatan antara barang dan jasa yang berbeda-beda untuk memaksimalkan kesejahteraan mereka. Menurut Sopiah dan Syihabudhin (2008:13) perilaku konsumen bukanlah sekedar mengenai pembelian barang. Lebih dari itu, perilaku konsumen adalah suatu hal yang dinamis, yang mencakup suatu hubungan interaktif antara efektif dan kognitif, perilaku dan lingkungan. Perilaku konsumen melibatkan pemikiran dan perasaan yang mereka alami serta tindakan yang mereka lakukan dalam proses konsumsi (Peter dan Olson, 2013, terjemahan Dwiandani, 2013:6). Nutisusastro (2013:33) berpendapat bahwa perilaku konsumen sebenarnya merupakan tahapan-tahapan langkah yang ditempuh dan dilakukan oleh seseorang atau individu atau kelompok orang dalam rangka memenuhi kebutuhan dan keinginannya.

Menurut Sangadji dan Sopiah (2013:9) Menyimpulkan pengertian perilaku konsumen yaitu: (1) Disiplin ilmu yang mempelajari perilaku individu, kelompok, atau organisasi dan proses-proses yang digunakan konsumen untuk menyeleksi, menggunakan produk, pelayanan, pengalaman (ide) untuk memuaskan kebutuhan dan keinginan konsumen, dan dampak dari proses-proses tersebut pada konsumen dan masyarakat. (2) Tindakan yang dilakukan oleh konsumen guna mencapai dan memenuhi kebutuhannya baik dalam penggunaan, pengkonsumsian, maupun penghabisan barang dan jasa, termasuk proses keputusan yang mendahului dan yang 
menyusul. (3) Tindakan atau perilaku yang dilakukan konsumen yang dimulai dengan merasakan adanya kebutuhan dan keinginan, kemudian berusaha mendapatkan produk yang diinginkan, mengkonsumsi produk tersebut, dan berakhir dengan tindakan-tindakan pasca pembelian, yaitu perasaan puas atau tidak puas. Dari kelima pendapat di atas, peneliti lebih cenderung menyetujui pendapat menurut Sangadji dan Sopiah pada poin ketiga. Perilaku konsumen yaitu suatu tindakan atau perilaku yang dilakukan oleh konsumen karena memiliki suatu kebutuhan, kemudian konsumen tersebut berusaha untuk mendapatkan atau memenuhi kebutuhannya dengan cara membeli produk yang sesuai dengan kebutuhannya, kemudian konsumen tersebut mengkonsumsi produk tersebut, setelah itu konsumen akan merasa puas atau tidak akan produk tersebut.

Berdasarkan Peraturan Menteri Perdagangan Republik Indonesia Nomor 53/MDAG/PER/12/2008 Tentang Pedoman Penataan Dan Pembinaan Pasar Tradisional, Pusat Perbelanjaan Dan Toko Modern Bab 2 Pendirian Pasar Tradisional, Pusat Perbelanjaan Dan Toko Modern Pasal 2 Ayat 1 menyebutkan lokasi untuk Pendirian Pasar Tradisional Pusat Perbelanjaan dan Toko Modern wajib mengacu pada Rencana Tata Ruang Wilayah Kabupaten/Kota dan Rencana Detail Tata Ruang Wilayah Kabupaten/Kota terrmasuk peraturan zonasinya. Dalam Peraturan Daerah Kota Madiun Nomor 06 Tahun 2011 Tentang Rencana Tata Ruang Wilayah Kota Madiun Tahun 2010-2030 Paragraf 2 Tentang Kawasan Peruntukan Perdagangan Dan Jasa Pasal 35 Ayat 6 menyebutkan rencana pengelolaan kawasan perdagangan dan jasa antara lain meliputi: (a) pengembangan pertokoan diarahkan pada kawasan baru atau pada kawasan yang kurang berkembang; (b) pengembangan toko dan warung yang menyediakan barang kebutuhan sehari-hari diarahkan menyatu dengan permukiman penduduk; (c) pengembangan sentra-sentra pedagang kaki lima (PKL) di kawasan pusat pelayanan sekaligus sebagai daya tarik wisata; (d) perdagangan skala regional dilengkapi dengan pusat-pusat perbelanjaan, perdagangan grosir, maupun sektor jasa; dan (e) perdagangan jasa skala kota diarahkan pada jalan-jalan utama kota dengan jenis atau kegiatan perdagangan dan jasa yang mempunyai bangkitan atau pergerakan yang rendah. Kondisi ini dapat dijumpai di kota Madiun. Salah satu contoh yakni pasar tradisional Sleko. Di sekitar pasar tradisional sleko dengan jarak kurang dari 500 meter terdapat pasar retail Indomaret Pasar Sleko yang beroperasi. Dan dalam jarak kurang lebih 600 meter ada pasar retail Alfamart CV Araya yang beroperasi.

Sopiah dan Syihabudhin (2008:4) berpendapat bahwa pelanggan kini semakin kritis terhadap toko yang akan dimasukinya. Mereka kini lebih terpelajar, lebih mempertimbangkan harga, cepat habis kesabarannya, dan tidak mudah memaafkan. Argumen yang mengatakan bahwa dengan tumbuh pesatnya pasar modern seperti Alfamart dan Indomaret merupakan penyebab utama tersingkirnya pasar tradisional tidak seluruhnya benar. Hampir seluruh pasar tradisional di kota Madiun masih banyak yang beroperasi. Banyak para pedagang di pasar tradisional masih memiliki pelanggan setia. Dengan masalah internal seperti buruknya manajemen pasar, sarana dan prasarana yang minim dan minimnya bantuan permodalan yang tersedia bagi pedagang tradisional, keadaan ini secara tidak langsung menguntungkan pasar modern Alfamart dan Indomaret.

Faktanya untuk saat ini pedagang tradisional Sleko yang terkena imbas langsung dengan keberadaan pasar modern Alfamart dan Indomaret yaitu para pedagang yang menjual produk yang sama dengan yang dijual di kedua tempat tersebut. Meskipun demikian, para pedagang yang menjual sayur-sayuran, daging, ikan, ayam, buahbuahan, peralatan rumah tangga dan lain-lain masih bisa bersaing dengan pasar 
modern Alfamart dan Indomaret mengingat masih banyak konsumen yang memilih ke pasar tradisional untuk membeli produk tersebut.

Penelitian terdahulu yang dilakukan oleh Sukesi Dan Sugiyono (2009) hasil dari penelitian ini yaitu kurang lebih $36 \%$ pedagang tradisional di pasar tradisional mengatakan bahwa pengunjung stand saat ini lebih sedikit jumlahnya dibandingkan lima tahun yang lalu (sebelum banyak berdiri pasar modern) dan hanya 33,3\% yang mengatakan jumlah pengunjung stand saat ini lebih banyak dibandingkan lima tahun yang lalu. Menurut pendapat responden, faktor utama yang menyebabkan terjadinya penurunan jumlah pengunjung dibandingkan lima tahun yang lalu atau sebelumnya adalah makin bertambahnya pasar modern di sekitar pasar tradisional. Perubahan lain yang dirasakan pedagang tradisional adalah penurunan volume penjualan yang dirasakan oleh $34,7 \%$ pedagang (volume penjualan saat ini lebih sedikit dibandingkan lima tahun yang lalu). Penurunan tersebut bervariasi mulai kurang dari $10 \%$ hingga di atas $30 \%$.

Syaharudin dan Sunardi (2013) hasil menunjukkan bauran pemasaran harga, dari hasil analisis dapat dinyatakan bahwa persepsi konsumen terhadap harga barang dagangan di minimarket (ritel modern) lebih mahal daripada harga barang ritel tradisional $(40 \%)$. Meskipun harga barang dagangan di minimarket (ritel modern) lebih murah, namun jika lokasi ritel modern jaraknya jauh dengan domisili konsumen, para konsumen tidak serta merta terpengaruh untuk membeli di ritel modern karena konsumen mempertimbangkan biaya transportasi. Hasil penelitian juga membuktikan bahwa promosi, desain toko, bangunan ritel, rancangan ritel yang baik beserta variasi barang dagangan yang disajikan dapat memberikan dampak emosional pada konsumen dan pada akhirnya konsumen terpengaruh untuk membeli barang kebutuhannya.

Berdasarkan uraian latar belakang di atas, maka peneliti tertarik menjawab permasalahan tentang dampak keberadaan pasar modern Alfamart dan Indomaret terhadap pasar tradisional Sleko di Kota Madiun, serta apakah keberadaan pasar modern Alfamart dan Indomaret menyebabkan menurunnya aktivitas pasar tradisional Sleko di Kota Madiun.

\section{METODE PENELITIAN}

Dalam penelitian ini, pendekatan yang dilakukan adalah melalui pendekatan kualitatif. Menurut Suparlan (dalam Patilima, 2013:61) menyebutkan pendekatan kualitatif yang dianalisis bukan variabel-variabelnya, melainkan hubungannya dengan prinsip-prinsip umum dari satuan-satuan gejala lainnya dengan menggunakan kebudayaan masyarakat yang bersangkutan. Menurut Afrizal (2014:11) pendekatan kualitatif mengacu kepada perspektif teoritis tertentu, biasanya adalah perspektifperspektif yang berada di dalam paradigma post-positivistis, seperti fenomenologi dan interaksionisme simbolik. Pendekatan kualitatif dilakukan peneliti untuk mengetahui kondisi yang akan diteliti dengan cara berinteraksi baik dengan wawancara atau observasi kepada informan. Penelitian ini menggunakan pendekatan kualitatif dikarenakan peneliti bertujuan memahami situasi dan kondisi suatu kebudayaan, fenomena, peristiwa, maupun kejadian dalam individu, kelompok atau masyarakat.

Jenis penelitian yang digunakan yaitu deskriptif kualitatif, Moleong (2007:11) menyatakan bahwa penelitian deskriptif kualitatif data yang dikumpulkan berupa kata-kata, gambar, dan bukan angka. Artinya data dalam penelitian berisi kutipankutipan untuk memberi gambaran penyajian laporan tersebut.

Penelitian ini berisi kutipan-kutipan untuk memberi gambaran penyajian laporan tersebut yang bertujuan untuk menjelaskan dan mendeskripsikan dampak 
keberadaan pasar modern Alfamart dan Indomaret terhadap pasar tradisional Sleko di Kota Madiun.

Sumber data dalam penelitian ini yaitu sumber data primer, artinya sumber data yang diperoleh secara langsung. Untuk mempermudah mengidentifikasi sumber data penulis mengidentifikasikannya menjadi 3 tingkatan huruf $\mathrm{p}$ dari bahasa Inggris, yaitu: $\mathrm{P}=$ Person sumber data berupa orang (Pedagang di Pasar Tradisional Sleko Kota Madiun, Pembeli baik di Pasar Tradisional mapun di Pasar Modern Alfamart dan Indomaret); $\mathrm{P}=$ Place, sumber data berupa tempat (bertempat di Pasar Tradisional Sleko Kota Madiun dan Alfamart serta Indomaret); dan P = Paper, sumber data berupa simbol (tanda-tanda berupa huruf, angka, gambar).

Tabel 3. Kerangka dan Jumlah Informan

\begin{tabular}{llr}
\hline \multicolumn{1}{c}{ Informasi yang Dicari } & \multicolumn{1}{c}{ Informan } & Jumlah \\
\hline $\begin{array}{l}\text { Informasi mengenai jumlah pedagang dan } \\
\text { literatur sejarah terbentuknya pasar Sleko }\end{array}$ & $\begin{array}{l}\text { Kepala Pasar } \\
\text { Sleko }\end{array}$ & 1 orang \\
\hline $\begin{array}{l}\text { Informasi mengenai dampak keberadaan pasar } \\
\text { retail Alfamart dan Indomaret }\end{array}$ & $\begin{array}{l}\text { Pedagang } \\
\text { Sembako }\end{array}$ & 4 orang \\
& Sayuran & 4 orang \\
& Buah & 4 orang \\
& Pembeli & \\
& Pasar Sleko & 4 orang \\
& Alfamart & 4 orang \\
& Indomaret & 4 orang \\
\hline TOTAL & & 25 orang \\
\hline
\end{tabular}

Cara pengumpulan data merupakan teknik yang digunakan untuk memperoleh informasi yang relevan dan akurat yaitu wawancara, angket pada lampiran 1, lampiran 2, lampiran 3, dan observasi. Wawancara kepada kepala pasar dan para pedagang di pasar Sleko, kuesioner yang dipakai dalam penelitian ini bersifat terbuka artinya responden dimintai pendapat mereka secara bebas, responden penelitian ini yaitu para pembeli baik di pasar Sleko maupun di Alfamart dan Indomaret, observasi dalam penelitian ini penulis melakukan observasi pada Pasar Sleko, Indomaret Pasar Sleko, dan Alfamart CV. Araya tentang aktivitas jual beli yang terjadi serta tentang bagaimana perilaku konsumen.

Pengecekan keabsahan data penelitian merupakan kegiatan penting bagi peneliti dalam upaya menjamin dan meyakinkan pihak lain, bahwa penelitiannya benar-benar sah. Usaha yang ditempuh oleh peneliti untuk memperoleh keabsahan data dengan menggunakan teknik triangulasi. Jenis triangulasi yang digunakan dalam penelitian ini adalah triangulasi dengan sumber. Menurut Patton (dalam Moleong, 2007:330) triangulasi sumber berarti membandingkan dan mengecek balik derajat kepercayaan suatu informasi yang diperoleh melalui waktu dan alat yang berbeda dalam penelitian kualitatif. Peneliti melaporkan hasil penelitian disertai penjelasan bagaimana yang dikemukakan tadi jelas akan menimbulkan derajat kepercayaan data yang diperoleh.

Bogdan (dalam Sugiyono, 2009:244) menyebutkan analisis data kualitatif adalah proses mencari dan menyusun secara sistematis data yang diperoleh dari hasil wawancara, catatan lapangan, dan bahan-bahan lain, sehingga mudah dapat dipahami, dan temuannya dapat diinformasikan kepada orang lain. Setelah data dari lapangan terkumpul dengan menggunakan metode pengumpulan data di atas, maka peneliti akan mengolah dan menganalisis data tersebut dengan menggunakan analisis secara deskriptif-kualitatif, tanpa menggunakan teknik kuantitaif. 


\section{HASIL PENELITIAN DAN PEMBAHASAN}

\section{Dampak Keberadaan Pasar Modern Alfamart Dan Indomaret Terhadap Pasar Tradisional Sleko Di Kota Madiun}

Dari data yang diperoleh dari hasil penelitian yang dilakukan dengan menyebarkan angket dan melakukan wawancara ditemukan beberapa pendapat dari berbagai sudut pandang mengenai dampak keberadaan pasar modern Alfamart dan Indomaret terhadap pasar tradisional Sleko di Kota Madiun. Berikut uraian mengenai keberadaan Alfamart dan Indomaret dilihat dari sudut pandang konsumen di Alfamart dan Indomaret, serta pedagang.

Terjadinya persaingan antara pasar tradisional dengan pasar modern Alfamart dan Indomaret sangat dipengaruhi oleh perilaku konsumen. Perilaku konsumen yaitu tindakan atau perilaku yang dilakukan oleh konsumen demi memenuhi kebutuhannya, kemudian konsumen tersebut berusaha mendapatkan atau memenuhi kebutuhannya dengan cara membeli produk yang sesuai dengan yang diinginkannya. Faktor-faktor yang mempengaruhi perilaku konsumen yaitu faktor eksternal dan faktor internal. Faktor eksternal terdiri dari budaya, kelas sosial, keluarga, kelompok referensi dan kelompok sosial. Sedangkan faktor internalnya terdiri dari motivasi, persepi, belajar, kepribadian dan konsep diri, kepercayaan dan sikap. Dengan faktor tersebut konsumen akan memilih berbelanja di pasar tradisional atau berbelanja di Alfamart maupun di Indomaret.

Akan terjadi persaingan apabila konsumen lebih memilih salah satu diantara pasar tradisional dengan retail Alfamart dan Indomaret. Konsumen saat ini lebih mengutamakan kenyamanan saat berbelanja walaupun harga barang bisa berbeda dengan adanya tambahan pajak barang. Karena bagi konsumen berbelanja kebutuhan bukan hanya bersifat membeli, akan tetapi para konsumen saat ini berbelanja juga sebagai suatu hiburan atau refreshing.

Jika dilihat dari sudut pandang pasar tradisional, keberadaan Alfamart dan Indomaret yang berlokasi dekat dengan pasar tradisional sangat mempengaruhi keadaan usaha dagang. Para pedagang mengemukakan bahwa banyak konsumen saat ini yang berbelanja di Alfamart dan Indomaret, keberadaannya mengganggu, keberadaannya jangan dekat pasar, dan lain-lain. Pasar tradisional merupakan cerminan suatu masyarakat dan wadah untuk masyarakat menengah ke bawah sebagai alat lahan usaha mata pencaharian, dimana keberadaan pasar tradisional tersebut apakah dapat dipertahankan atau tidak. Jika para pedagang merasa terganggu akan keberadaan Alfamart dan Indomaret yang berlokasi di dekat pasar tradisional, maka keberadaan pasar tradisional akan terancam.

Menurut kepala pasar, ada sebagian pedagang yang omset dan konsumennya berkurang, dan ada juga pedagang yang tidak terpengaruh seperti pedagang sayuran, plastik, elektonik, dan lain-lain. Jenis barang atau komoditi yang dibeli oleh konsumen di Alfamart dan Indomaret bisa didapat di pasar, karena produk yang dijual beraneka jenis dan merek kebanyakan dari konsumen lebih memilih berbelanja di Alfamart atau Indomaret. Mengenai dampak keberadaan Alfamart dan Indomaret dari berbagai sudut pandang, maka Alfamart dan Indomaret sangat mempengaruhi (berdampak) terhadap penjualan di pasar tradisional Sleko.

Hal ini sangat dipengaruhi oleh perilaku konsumen. Perilaku konsumen terdiri dari faktor eksternal dan faktor internal. Yang terjadi saat ini perilaku konsumen sangat di pengaruhi oleh faktor internal, seperti motivasi, persepsi, kepribadian dan konsep diri, serta kepercayaan dan sikap. Faktor motivasi dalam konsumen yaitu tertarik berbelanja di Alfamart dan Indomaret karena akan mendapat poin. Faktor persepsi yaitu persepsi konsumen jika berbelanja di Alfamart dan Indomaret itu 
nyaman, sejuk, rapi, bersih, pelayanannya baik, ramah. Faktor kepribadian dan konsep diri dalam konsumen yaitu konsumen menjunjung akan image merek dan image penjual, oleh karena itu jika konsumen merasa puas akan satu pembelian di Alfamart atau Indomaret maka konsumen tersebut akan cenderung balik kembali. Dan jika faktor kepercayaan dan sikap yaitu kepercayaan adalah keyakinan, konsumen meyakini bahwa belanja di Alfamart dan Indomaret bisa mendonasikan uangnya untuk kepentingan masyarakat yang membutuhkan.

\section{Analisis Keberadaan Pasar Modern Alfamart Dan Indomaret Terhadap Aktivitas Pasar Tradisional Sleko Di Kota Madiun}

Pedagang sayuran dan pedagang buah tidak mengalami pengaruh terhadap omset dan konsumen adanya Alfamart dan Indomaret. Sedangkan bagi pedagang sembako mengalami omset menurun dan berkurangnya konsumen. Karena barang yang dijual oleh pedagang sembako sebagian besar Alfamart dan Indomaret juga menjualnya, bahkan Alfamart dan Indomaret menyediakan berbagai jenis merek sehingga konsumen bisa lebih memilih sesuai dengan yang diinginkan. Oleh karena itu, keberadaan Alfamart dan Indomaret tidak menyebabkan menurunnya aktivitas pasar tradisional Sleko dalam hal jual beli. Walaupun adanya Alfamart dan Indomaret yang berlokasi di dekat pasar, masih ada konsumen yang berbelanja ke pasar Sleko.

\section{Pasar Tradisional Sleko Versus Pasar Modern Alfamart - Indomaret}

Penelitian yang telah dilakukan menunjukkan bahwa pasar tradisional Sleko vs Alfamart dan Indomaret masing-masing memiliki kelebihan dan kekurangan, baik dari sudut pandang pedagang maupun dari sudut pandang para konsumen.

Hasil wawancara peneliti dan pedagang dapat disimpulkan bahwa pedagang di pasar Sleko masih menggunakan fasilitas itu masih manual. Misalnya pada pedagang buah yang memiliki keterbatasan modal untuk mengadakan tempat penyimpanan buah dagangannya yang menyebabkan barang dagangannya mudah busuk, sementara pedagang dituntut menyediakan berbagai macam pilihan buah untuk dijual. Terlebih lagi jika dalam satu hari tidak ada konsumen yang membeli buah maka akan mengalami kerugian.

Selain itu, terbatasnya ruang atau kios yang dimiliki oleh para pedagang di pasar Sleko yang menyebabkan para pedagang kekurangan tempat untuk menyimpan barang dagangannya. Sementara semakin lengkapnya jenis dagangan di suatu kios membuat para konsumen lebih tertarik untuk datang untuk membeli. Jadi, hal inilah yang menyebabkan daya saing antar pedagang tinggi.

Kesimpulan dari hasil angket konsumen menyatakan bahwa para konsumen merasa nyaman saat berbelanja di Alfamart dan di Indomaret karena kebersihannya terjaga, keramahan pelayan, adanya promo pada barang-barang tertentu, adanya fasilitas pembayaran yang modern, banyaknya jenis barang yang disuguhkan dan mudahnya dalam mengakses barang yang ingin dibeli. Dibandingkan dengan saat membeli di pasar tradisional Sleko yang mana kondisi pasar gelap dan kurang pencahayaan yang menyebabkan kurangnya minat untuk berbelanja di sana.

\section{SIMPULAN}

Kesimpulan yang dapat diambil adalah dampak keberadaan pasar modern Alfamart dan Indomaret terhadap pasar tradisional Sleko di Kota Madiun yaitu pedagang sayuran dan pedagang buah tidak mengalami pengaruh terhadap omset dan konsumen. Sedangkan dampak bagi pedagang sembako yakni mengalami turunnya omset dan berkurangnya konsumen. Oleh karena itu, keberadaan Alfamart dan 


\section{ASSEIS JURNAL AKUNTANSI DAN PENDIDIKAN

Indomaret tidak menyebabkan menurunnya aktivitas pasar tradisional Sleko dalam hal jual beli. Pasar Sleko pun masih memiliki konsumen walaupun keberadaan Alfamart dan Indomaret berlokasi di dekat pasar.

Berdasarkan hasil penelitian dan kesimpulan yang dikemukakan di atas, peneliti memberikan beberapa saran, yaitu: (1) merekomendasikan perbaikan pasar tradisional khususnya pasar tradisional Sleko agar lebih menarik dan nyaman bagi konsumen, (2) pasar tradisional agar tetap dilestarikan keberadaannya, (3) sebaiknya pemerintah mengevaluasi kembali penataan letak Alfamart dan Indomaret dengan pasar tradisional, (4) untuk penelitian selanjutnya, peneliti mengharapkan adanya penelitian terhadap dampak keberadaan retail modern lainnya terhadap pasar tradisional di Kota Madiun.

\section{DAFTAR PUSTAKA}

Afrizal. (2014). Metode Penelitian Kualitatif: Sebuah Upaya Mendukung Penggunaan Penelitian Kualitatif Dalam Berbagai Disiplin Ilmu. Cetakan Pertama. Jakarta: Rajawali Pers.

Arikunto, S. (2013). Prosedur Penelitian: Suatu Pendekatan Praktik. Cetakan Kelimabelas. Jakarta: Rineka Cipta.

Aryani, D. (2011). Efek Pendapatan Pedagang Tradisional Dari Ramainya Kemunculan Minimarket Di Kota Malang. Jurnal Dinamika Manajemen, 2 (2), 169-180.

Asribestari, R. dan Setyono, J. S. (2013). Pengaruh Daya Tarik Pasar Tradisional Dan Pasar Modern Terhadap Preferensi Konsumen (Studi Komparasi Pasar Karangayu Dan Giant Superdome). Jurnal Teknik PWK, 2 (3), 539-548.

Darmadi, H. (2013). Dimensi-Dimensi Metode Penelitian Pendidikan dan Sosial. Cetakan Kesatu. Bandung: CV Alfabeta.

Dharmmesta, B. S. dan Handoko, T. H. (2013). Manajemen Pemasaran: Analisis Perilaku Konsumen Edisi Pertama. Cetakan Keenam. Yogyakarta: BPFEYogyakarta.

Kotler, P., dan Keller, K, L. (2009). Manajemen Pemasaran. Edisi Ketiga Belas Jilid 1. Terjemahan oleh Adi Maulana dan Wibi Hardani. Jakarta: Erlangga.

Moleong, Lexy. J. (2007). Metodologi Penelitian Kualitatif. Bandung: PT. Remaja Rosdakarya.

Nitisusastro, M. (2013). Perilaku Konsumen: Dalam Prespektif Kewirausahaan. Cetakan Kedua. Bandung: CV Alfabeta.

Nuraini, E. dan Merdekawati, D. (2013). Ekonomi: Untuk SMA/MA Kelas X. Sidoarjo: Masmedia Buana Pustaka.

Patilima, H. (2013). Metode Penelitian Kualitatif. Cetakan Keempat. Bandung: CV Alfabeta.

Peraturan Daerah Kota Madiun No. 32 Th. 2011 Tentang Retribusi Pelayanan Pasar. (2011). Madiun: Pemerintah Kota Madiun.

Peraturan Daerah Kota Madiun Nomor 06 Tahun 2011 Tentang Rencana Tata Ruang Wilayah Kota Madiun Tahun 2010-2030. (2011). Madiun: Pemerintah Kota Madiun.

Peraturan Menteri Perdagangan Republik Indonesia Nomor 53/MDAG/PER/12/2008 Tentang Pedoman Penataan Dan Pembinaan Pasar Tradisional, Pusat Perbelanjaan Dan Toko Modern. (2008). Jakarta: Kementerian Perdagangan Republik Indonesia.

Peter, J. P. dan Olson, J. C. (2013) .Perilaku Konsumen dan Strategi Pemasaran. Terjemahan oleh Dwiandani, D. T. Jakarta: Salemba Empat. 
Probowati, A. (2011). Strategi Pemilihan Supplier Dalam Supply Chain Management Pada Bisnis Ritel, 7(1). Diakses pada 1 April 2016, dari http:/ / ejournal.umpwr.ac.id/index.php/segmen/article/view/611/585.

Rahayu, S. E dan Bahri, H. (2014). Studi Komparatif Perubahan Pendapatan Usaha Warung Tradisional Sebelum Dan Sesudah Adanya Warung Retail Modern Di Kecamatan Medan Timur. Jurnal Manajemen \& Bisnis, 14 (2), 151-165.

Sarwono, H. dan Sunyoto, D. (2014). Pengantar Ilmu Ekonomi Mikro: (Teori dan Soal). Edisi Terbaru. Yogyakarta: CAPS.

Sangadji, E. M. dan Sopiah. (2013). Perilaku Konsumen: Pendekatan Praktis Disertai Himpunan Jurnal Peneleitian. Edisi Pertama. Yogyakarta: ANDI.

Sukesi, Sugiyono. (2009). Dampak Keberadaan Pasar Pasar Modern Terhadap Pedagang Pasar Tradisional (Studi Kasus di Kota Balikpapan). DIE - Jurnal Ilmu Ekonomi dan Manajemen, 5 (4), 155-184.

Sunyoto, D. (2015). Manajemen Bisnis Ritel: Teori, Praktik, dan Kasus Ritel. Cetakan Pertama. Yogyakarta: CAPS.

Sunyoto, D. (2014). Praktik Riset Perilaku Konsumen: Teori, Koesioner, Alat, dan Analisis Data. Cetakan Pertama. Yogyakarta: CAPS.

Sugiyono. (2014). Memahami Penelitian Kualitatif. Cetakan Kesembilan. Bandung: CV Alfabeta.

Sugiyono. (2014). Metode Penelitian Kuantitatif, Kualitatif, dan Kombinasi (Mixed Methods). Bandung: CV Alfabeta.

Sugiyono. (2013). Metode Penelitian Pendidikan (Pendekatan Kuantitatif, Kualitatif, dan R\&D). Cetakan Ketujuh Belas. Bandung: CV Alfabeta.

Sugiyono. (2009). Metode Penelitian Kuantitatif, Kualitatif, dan R\&D. Cetakan Kedelapan. Bandung: CV Alfabeta.

Soliha, E. (2008). Analisis Industri Ritel Di Indonesia. Jurnal Bisnis Dan Ekonomi, 15, $128-142$.

Sopiah dan Syihabudhin. (2008). Manajemen Bisnis Ritel. Edisi Pertama. Yogyakarta: ANDI.

Utomo, T. J. (2011). Persaingan Bisnis Ritel Tradisional VS Modern. Fokus Ekonomi, 6(1), $122-133$. 


\section{LAMPIRAN}

Lampiran 1 contoh angket

\section{ANGKET}

\section{Responden}

Yang terhormat,

Dalam rangka untuk mengetahui Dampak Keberadaan Pasar Retail Alfamart dan Indomaret Terhadap Pasar Tradisional Sleko di Kota Madiun, peneliti berusaha mengumpulkan data tentang perilaku konsumen. Besar harapan peneliti agar responden bersedia memberikan informasi yang sesuai. Atas ketersediaan dan partisipasinya, peneliti ucapkan terima kasih.

\section{Hormat Saya, \\ Mahmudah Masyhuri}

\section{PETUNJUK PENGISIAN ANGKET}

Pertanyaan ini berupa isian, dimohon mengisi jawaban pada tempat yang telah disediakan.

\section{Identitas Responden di Pasar Sleko}

Nama

Jenis Kelamin :

Pekerjaan :

\section{A. Angket Terbuka}

1. Berapa kali Anda berbelanja di pasar Sleko dalam satu minggu?

Jawaban:

Apa alasan Anda berbelanja di pasar Sleko?

Jawaban:

Menurut Anda, apa yang membedakan belanja di pasar dengan di Alfamart dan Indomaret?

Jawaban:

Apakah ada faktor yang mempengaruhi minat belanja Anda di pasar Sleko? Jawaban:

Jenis barang/komuditi apa yang biasa Anda beli di pasar Sleko? Jawaban: 
Bagaimana tanggapan Anda mengenai pasar Sleko?

Jawaban:

Apa saran Anda untuk pasar Sleko kedepannya?

Jawaban:

Lampiran 2 contoh indikator wawancara

INDIKATOR WAWANCARA

A. Kepala Pasar Sleko Kota Madiun

1. Sejarah berdirinya pasar Sleko

2. Jumlah pedagang saat ini

3. Cara perekrutan pedagang

4. Para pedagang dimintai/dipungut biaya operasional atau tidak

5. Manajemen/pengelolaan pasar

6. Tanggapan mengenai aktivitas jual beli saat ini dan di 5 tahun terakhir

7. Tanggapan mengenai berdirinya Alfamart dan Indomaret

8. Tanggapan mengenai dampak keberadaan Alfamart dan Indomaret

9. Adakah pedagang yang "gulung tikar" akibat dari didirikannya Alfamart dan Indomaret

10. Alfamart dan Indomaret terhadap omset pedagang

11. Kebijakan seharusnya bagaimana

B. Pedagang

1. Awal mula berjualan di pasar Sleko

2. Pengelolaan toko

3. Dimintai/dipungut biaya operasional atau tidak

4. Kendala/masalah yang terjadi selama berjualan

5. Pendapatan per bulan

6. Tanggapan mengenai keberadaan Alfamart dan Indomaret

7. Pengeruh didirikannya Alfamart dan Indomaret

8. Tanggapan mengenai pengelolaan pasar Sleko

9. Saran untuk pasar Sleko kedepannya

10. Alfamart dan Indomaret:
a. Omset
b. Jumlah konsumen

11. Dukungan kebijakan pemerintah seperti apa 


\section{ASSETS}

Lampiran 3 contoh daftar pertanyaan wawancara kepala pasar

DAFTAR PERTANYAAN WAWANCARA

$\begin{array}{ll}\text { Responden } & \text { : } \\ \text { Nama } & \text { : }\end{array}$

: Kepala Pasar

:

\begin{tabular}{|l|l|l|}
\hline No & \multicolumn{1}{|c|}{ Pertanyaan } & Jawaban \\
\hline 1 & Bagaimana sejarah berdirinya pasar Sleko di Kota Madiun? & \\
\hline 2 & Berapa jumlah pedagang saat ini? & \\
\hline 3 & Bagaimana cara perekrutan pedagang di pasar Sleko? & \\
\hline 4 & Apakah para pedagang dimintai/dipungut biaya operasional? & \\
\hline 5 & Bagaimana manajemen/pengelolaan di pasar Sleko? & $\begin{array}{l}\text { Bagaimana tanggapan Anda mengenai aktivitas jual beli di pasar } \\
\text { saat ini dan di lima tahun terakhir? }\end{array}$ \\
\hline 7 & $\begin{array}{l}\text { Bagaimana tanggapan Anda mengenai berdirinya Alfamart dan } \\
\text { Indomaret di sekitar pasar? }\end{array}$ & \\
\hline 8 & $\begin{array}{l}\text { Bagaimana tanggapan Anda mengenai dampak keberadaan } \\
\text { Alfamart dan Indomaret? }\end{array}$ & $\begin{array}{l} \\
\text { Alfamah pedagang yang "gulung tikar" akibat didirikannya }\end{array}$ \\
\hline 9 & $\begin{array}{l}\text { Bagaimana pengaruh Alfamart dan Indomaret terhadap omset } \\
\text { pedagang? }\end{array}$ & \\
\hline 11 & Bagaimana kebijakan yang seharusnya? & \\
\hline
\end{tabular}

Yang Bertanggungjawab

Lampiran 4 contoh daftar pertanyaan wawancara pedagang

\section{DAFTAR PERTANYAAN WAWANCARA}

\section{Responden :Pedagang \\ Nama : \\ Jenis Dagangan :}

\begin{tabular}{|l|l|l|}
\hline No & \multicolumn{1}{|c|}{ Pertanyaan } & Jawaban \\
\hline 1 & Kapan awal mula Anda berjualan di pasar Sleko? & \\
\hline 2 & Bagaimana cara Anda mengelola dagangan/toko Anda? & \\
\hline 3 & Apakah Anda dimintai/dipungut biaya operasional? & \\
\hline 4 & Apa masalah/kendala yang terjadi selama Anda berjualan? & \\
\hline 5 & Berapa pendapatan Anda per bulan? & \\
\hline 6 & $\begin{array}{l}\text { Bagaimana tanggapan Anda mengenai keberadaan Alfamart dan } \\
\text { Indomaret? }\end{array}$ & \\
\hline 7 & $\begin{array}{l}\text { Apakah ada pengaruh dengan didirikannya Alfamart dan } \\
\text { Indomaret terhadap dagangan Anda? }\end{array}$ & \\
\hline 8 & Bagaimana tanggapan Anda mengenai pengelolaan pasar Sleko? & \\
\hline 9 & Apa saran Anda untuk pasar Sleko kedepannya? \\
\hline 10 & $\begin{array}{l}\text { Bagaimana pengaruh keberadaan Alfamart dan Indomaret } \\
\text { terhadap omset dan jumlah konsumen Anda? }\end{array}$ & \\
\hline 11 & Dukungan kebijakan seperti apa yang diberikan oleh pemerintah? & \\
\hline
\end{tabular}

Yang Bertanggungjawab 